DOI: https://doi.org/10.47405/mjssh.v6i3.709

\begin{tabular}{|c|c|}
\hline 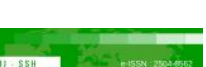 & Malaysian Journal of Social Sciences and Humanities (MJSSH) \\
\hline Malaysian Journal of & Volume 6, Issue 3, March 2021 \\
\hline (Mu-ssH) & e-ISSN : 2504-8562 \\
\hline & $\begin{array}{l}\text { Journal home page: } \\
\text { www.msocialsciences.com }\end{array}$ \\
\hline
\end{tabular}

\title{
Writing Lyrics in English to An Indigenous Iban Song-Towards the Efficacy of Culturally Responsive Pedagogy
}

\author{
Bethrace Sylvester ${ }^{1}$, Azlina Abdul Aziz ${ }^{2}$ \\ ${ }^{1}$ Sekolah Kebangsaan Nanga Merit, Limbang, Sarawak \\ ${ }^{2}$ Fakulti Pendidikan, Universiti Kebangsaan Malaysia (UKM) \\ Correspondence: Bethrace Sylvester (grazillegisellebeth@gmail.com)
}

\begin{abstract}
The main purpose of this study was to examine the use of Indigenous Iban song in enting 2 pupils' writing skills. Culturally responsive pedagogy is a progressive approach that shapes the future learning process This research was conducted in a rural school of the Limbang district in Sarawak. The participants of this research comprised of 20 pupils from Year 4 until Year 6. Year 6 pupils were included as they were not sitting for UPSR due to Pandemic. Action Research with the model Kemmis \& McTaggart employed in this study. The findings from the questionnaires indicated a high level of agreement from the participants on implementation of writing lyrics in English to an indigenous Iban song.
\end{abstract}

Keywords: indigenous Iban, culturally responsive pedagogy, action research, writing

\section{Introduction}

It is well regarded that English is a global language (David, 2003). In Malaysia, it is the second official spoken language. To be able to master the languages in Malaysia's education policy is beyond debate especially when it comes to the use of Bahasa Malaysia and English languages (Malaysia Education Blueprint 2013-2025). With that, it is best to create an atmosphere that can increase the learners interest through ways of teaching that resembles the one which is natural to them. In the education field especially for primary school level, learning English cannot be based solely on the provided textbook. The teachers should consider social and cognitive developments of the learners while teaching the language. Thus, they should consider creating or adapting materials to suit the learners' interest, social and cognitive developments.

The use of songs is one of the best ways to help the learners to understand English better. As mentioned by Saricoban and Metin (2000), the use of songs can help in improving the four skill areas which consist of listening, speaking, reading and speaking skills. The most vital part would be having the learners to develop a positive attitude towards the learning process. The use of songs can create a positive atmosphere and lower the affective filter. It is believed to be an efficient way of learning the four skills. With the help of using song lyrics, it can help them to memorise better especially songs that are related to their culture. Using songs can be an effective way to promote language acquisition. Their cultural awareness will be developed too since music exists in different cultures and helps in reflecting one's culture. In reality, learners in remote schools are most likely to be exposed with catchy songs not only during festival time but also in their daily lives. As the use of the internet and other technology are 
limited, they rely much on the radio, the only source of entertainment for them. So, most of them are delighted when an Iban song is played on the radio. By considering these factors, this study is conducted to find out the effectiveness of writing an English lyric to an indigenous Iban songs towards the efficacy of a culturally responsive pedagogy.

\section{Literature Review}

The literature review section provides a clear description of the published information and data in the relevant topic. The advice and sources are evaluated in the literature review section. This study aims at demonstrating the efficacy of culture responsive pedagogy and learning processes among rural students by writing lyrics in English to an indigenous Iban song. The role and importance of the culture responsive pedagogy been discussed in this section. In addition to that, relevant theories and efficacies of the teachers in delivering the teaching lesson also been illustrated. Relevant theories that related to the positiveness of the cultural responsive pedagogy been discussed as well. Empathy and preparations for the culture responsive pedagogy needs to be demonstrate.

\section{Importance of Culturally responsive learning in schools}

Culturally responsive teaching can be considered such as teaching strategies that contain culturally relevant pedagogy and includes multicultural or cross-cultured learners. The learning ability and quality can be challenged due to the cultural differences among the learners and teachers in the process of learning and teaching in ESL classroom. Culturally responsive teaching mainly supports the ethical diversity among learners, performance styles, prior experience and cultural knowledge so that the learning becomes efficient for the learners (Khalifa et al,. 2016). The culture responsive pedagogy adaptation helps in establishing a specific culture in the position of strength while enhancing social and academic achievements (George, 2018). Certain teachers who lean towards culturally responsive teaching are grounded in teaching conceptions, social relationships and pedagogical practices which helps in elevating social and academic justice for the learners. It also concentrates on identifying cultural differences as a strength while delivering education.

Such teaching also promotes establishing a relevant connection with the cultural experience of the learners in rural area and analyse the cultural background of them as well (Lucey \& White, 2017). The learning experience of similar cross-cultural learners is shared among them so that they become motivated. Cultural-inclusion teaching involves such teaching techniques that need to interact with the local communities and special connection with the family members (Bassey, 2016). The cultureinclusion teaching allows learners to be the agent to bring change in the society through the acquisition of education in an innovative way. The need for equality and racial pride are implemented among the perception of culturally-diversified students.

Culturally responsive pedagogy includes utilisation of the existing cultural knowledge of the learners to learn innovative languages and teaching (Lucey \& White, 2017). The learning efficacy and ethics are taken into consideration while opting for culture-included teaching. In a recent study by Bassey (2016), it has been observed that African-American students were trained and educated through rap music for teaching poetry (Heitner \& Jennings 2016). Eventually, the specially trained students outperformed those students who did not adopt the culture-inclusive methods. Similar examples revealed a program that included community parents to share their knowledge and wisdom to the students. The simultaneous inclusion of both standard language and community languages helped respective students to become expert in both the selected languages.

Culturally responsive teaching and learning provide social justice to the learners and their community language. The needs of different cultural students and their diversity can be mitigated through delivering the cultural responsiveness as a part of teaching (Lucey \& White, 2017). 


\section{Relevant Theories}

The culture responsive pedagogy perceptions and its features can be explained with the help of relevant theories and models with respect to this. Some of the relevant theories can be mentioned as Culture Deficit theory, expectancy theory and the theory of cultural difference. The theories are relevant to the cultural differences of students and teachers in the differentiation of the community members.

The Culture Deficit Theory suggests that related deficiencies prevailed in the home environment reflects in the shortcomings of behaviours, knowledge and skills among students in the school environment (theedadvocate.org, 2020). The development of vocabulary in a particular language depends on its frequency of utilisation or verbal interaction with the community people. According to Wildavsky (2018), the process of vocabulary development does not get the desired outcome while opposed by the oppressive language. Therefore, it is mandatory to have a balance between the two environments while providing effective learning to the students.

The Expectation theory shown that the performance of the students is severely affected by the respective expectation of the teachers from their individual students. The higher expectation can act as motivation to the students, but in some cases, unexpected expectations may generate pressure for learning (Tamrin et al., 2018). In most of the cases, it has been observed that the teachers tend to expect poor academic performance from the cultural, ethnic, racial and rural backgrounds. The teaching approach also aligns with the level of expectancy from the students, and as a consequence, the ethnic students tend to perform respectively lower than others. The average students can even outperform others when the teachers believe in their expertise and mentor them with a higher level of expectations. The students tend to perform at a higher academic level when they are driven by a selffulfilling prophecy (Rogachi et al., 2018). Those students also outperform as they aspire to meet with the desired expectations of the teachers. On a contrary note, the students who perform low grade in the academic output tend to meet the lower expectations of the teachers in their performances.

The theory of cultural difference states that respective students from separate cultural settings may perform differently in learning and education. The teachers are required to be aware of the certain differences in the home environment and school atmosphere of the students (theedadvocate.org, 2020). The educational approach of the students from a cultural or ethnic background may have difficulty in acquiring and adapting the teaching techniques and process delivered in the mainstream educational system. The teaching methods and perceptions utilised by the teachers must focus on the cultural notions and beliefs among the students. They must not be hurt by the differences in the cultural perspective of the teachers. The differences in the culture may generate confusion among them as well. Therefore, the teachers must include cultural beliefs and the notion of the cultural groups in the study of the standard languages and teachings. The theory of culturally responsive pedagogy suggests that the centralised cultural strength of the students can be utilised in the process of learning and writing second language. The principle states the context of relevance while learning an unknown factor (Samuels et al., 2017). The students can easily relate to the materials that are familiar to their knowledge. The adaptation process become flexible and easy when writing skills are aligned with song lyrics for better learning of the second language.

\section{Preparation and Empathy for Culturally Responsive Pedagogy}

The principal factor that majorly influences the concept of culture reflected educational approach is the motive and empathy among the education providers (Warren, 2018). The teachers and administrative personnel need to internalise the importance and positive impacts of culture-responsive pedagogy to be success in its implementation. The teachers need to understand the objective of installation of such programmes in the educational settings. Periodic observation of the achievements towards success is also mandatory to execute during the program (Samuels et al,. 2017). The teachers and education providers need to commit anti-racist teaching, perceptions, anti-oppressive behaviour and the concept 
of social justice to the students and their related community members. Empathy generates trust and confidence on the opposite side. In this way, the committed behaviour of the active personnel towards social justice will generate faith and confidence in the community people regarding their ability (Carter Andrews et al., 2018).

The preparation that culturally responsive teachers must take is regarding knowledge creation. The knowledge that can help teachers in committing their performance is regarding different cultures and related features. Cultural knowledge acquisitions let mentors understand the positive and conventional factors eventually (Carter Andrews et al., 2018). The teacher needs to insert the positive factors and blend those factors with modern educational techniques for example using song in teaching.

Therefore, the primary concern of the teachers must be the acquisition of the knowledge regarding the culture that they aspire to include in the mainstream learning process. The teachers can grow empathy by generalising the cultural aspects and internalising those with their teaching proficiencies (Carter Andrews et al., 2018). The cultural knowledge of self can be applying in this technique as well. The teachers can establish themselves in such a position where they can bridge the gaps in the educational society (Samuels et al., 2017). Preparedness and empathy are highly required for the avocation of effective and equal opportunities to all irrespective of their cultural or racial identity.

\section{Effect of Culture Responsive Pedagogy Among the Learners}

Culture responsive pedagogy has been proposed as a robust technique for enhancing engagement and achievement among students. The cultural gaps and achievement gaps between the mainstream and culturally background learners can be reduced through the efficient method (Fasasi, 2017). The learners' perspective is necessary to gather while understanding the effectiveness of culture responsive teaching. In a recent study, it has been noted that the learning process becomes lively and interesting to the learners when they are allowed to relate their academic learning with real-life examples. For example, the learners required to write lyric in English by using "Berkikis Bulu Betis" song. This Iban song is well known in Malaysia and had come with various version. In the case of cultural background learners, the opportunity for relating academic subjects are less when they are educating in a cultureexclusive environment (Tanner, 2019). The education technique becomes dull and uninteresting and it is the main reason behind getting poor achievements.

Critical consciousness generates among cultural and ethnic students while leaning towards culturerelevant education. For example, a certain group of students learn science practice in a larger society and discuss its facts (De Jager, 2019). On a contrary note, another group of learners analyses the scientific factors in their local community with scientific techniques to learn the same scientific model. The second group of learners may reflect practical ideas and culture-related to the project and can get a chance to apply their educational knowledge in cultural and societal aspects. The learners learn the value of their traditional culture and initiate respect for them.

In fact, the learners can be more protective of their culture while providing standard language practice for the purpose of career achievement. The learners who are trained in culture related teachings, mainly remain faithful in their culture even after accomplishing higher achievement in their studies (Fasasi, 2017). They learn to respect the culture and traditions of other communities. The community members tend to support the educational approach to the learners when they find the cultural aspects are being respected in the educational programmes (De Jager, 2019).

The learners tend to adapt and understand a wide range of people from differential race, ethnic and cultural background in their classroom (Tanner, 2019). The cultural knowledge and expertise also enhance with respect to those who were educated in mainstream educational programs only. According 
to Morrison et al. (2019), most importantly, the teacher-student relationship becomes close when they value each other's' perceptions and beliefs.

\section{Challenges and Benefits of Culturally Responsive Pedagogy}

The teaching process in a cross-cultural or multicultural teaching atmosphere is facilitated by culturally-responsive teaching practices or pedagogy. Culturally responsive pedagogy helps to empower learners with cultural integrity and awareness about cultural diversity. As commented by Pirbhai-Illich, Pete \& Martin (2017), the culturally responsive teaching practices increase cultural awareness by encouraging learners to explore different cultures. With that, these teaching-learning processes improve the knowledge of English languages and reduce the barriers in learning culturally diverse aspects and materials. Bridging the gap in communication and exploring other cultures increase motivation among learners to learn about the differences and accept them that result in positive learning approaches.

The benefits of culturally responsive teaching involve awareness, understanding and concepts about cultural differences and learning of the differences. As stated by Samuels (2018), language learning requires specific motivation and related cultural concepts to integrate learning in regular practices. Thus, culturally responsive pedagogy has the potential for cultural awareness that increases the motivation to learn about that language and culture more.

\section{Elimination of discrimination}

Cultural awareness and understanding can help in removing specific discrimination. Moreover, the culturally responsive teaching-learning can ensure the interaction of learning with cultural respect and understanding that increase motivation among children.

\section{Improvementin interaction}

Culturally inclusive classroom environments and mutual respect with understanding help in creating a positive atmosphere that increases interaction among students. The interaction among students helps in obtaining a preliminary or introductory concept of foreign language (Samuels, Samuels \& Cook, 2017).

\section{Increased personalisedlearning}

Cultural inclusion is perceived to be effective in generating personalised learning features. Cultural integrity increases self-learning notions and creates scope for personalisation to facilitate learning, which is to be motivated by facilitators.

\section{Mutual understanding and interest}

Acknowledge and respect is part of developing a mutual understanding and interest that help in developing a positive view about the foreign culture, its language and norms (Pirbhai-Illich, Pete \& Martin, 2017).

\section{Knowledge enhancement}

Understanding and acknowledging the new and foreign culture during culturally-responsible pedagogy creates a scope for understanding the differences with a positive view. It leads to the understanding of 
language and developing specific interest. However, the strategy has faced challenges of suitable navigation in the learning and teaching proceeds with lack of efficiency among teachers.

The diversity is often treated adversely with lack of efficient classroom management, curriculum planning and implementing them in the process. As stated by Gay (2015), the recognition of differences and proper understanding is required in culturally-responsive teaching processes, which is often neglected with reference to teachers' inefficiency. Moreover, the presentation by teachers as a role model and presenting the specific aspects of English language remain missing that can reduce the positive aspects of culture-induced learning. On the other hand, education media is responsible for integrating specific strategies that promote cross-cultural practices. Nonetheless, the challenges can make the princess more complex and diverge from the actual content and syllabus embedded learning.

\section{Role of song lyrics in developing writing skills}

Language is considered the most significant source of communication among the adolescents. The conveyance of messages, feelings, opinions, ideas and perceptions can be executed in an efficient manner through this process. There are four skills that are utilised for generating expertise in any subjects such as reading, listening, writing, and speaking (MUBAROK, 2019). The most productive skills among the aforementioned features are speaking and writing. The most difficult skills for the learners in this case is the writing skills because the learner requires full potential of the language to learn the technique to write. The difficulties are generated through explaining, organising and generating ideas into certain readable and understandable texts. On the other hand, lyrics can be characterised as the application of poetic expressions, speech, conversational and rhythmic expressions (Shayakhmetovaet al., 2017). Utilisation of song lyrics can be related with the strategy of material adaptation where the mentors use certain material in the context of learning to make the learning process rewarding and remarkable.

Most of the experts believe that people tend to make a pattern of emotion with the most common lyrics. Therefore, utilisation of song lyrics in the classroom can be relatable for the students. The engagement of the students towards the foreign language can be enhanced through the inclusion of song lyrics in native language as a tool. The vocabulary generation and idea development can be done easily through the utilisation of song lyrics. The writing skills can be improved through the innovative process as well (Patrick, 2019). As mentioned in Krashen's hypothesis, the writing skills of second language learning must imply acquisition learning, monitoring, natural order maintenance, input and application of effective filters.

From the above discussion, it can be concluded that culture-responsible pedagogy is a progressive approach that shapes the future learning process. Social justice and educational equity rights are internal concepts that reflect their importance. Cultural equity is also an integral factor that motivates the approach among students and teachers. Standardisation of culture and language throughout the world is not expected by the different cultural people. On the other hand, compromising of languages for the educational attainment can cease the cycle of growth of a particular community of people. The right for education is equal among all the groups, communities, races and culture.

The perception of the culture-responsive instructional technique directly promotes social equality concepts. The constructivist nature of society is also reflected in culture-relevant teaching approaches. In addition to that, the cultural languages are inherent and fluent among the students. Therefore, relatedness of that cultural fluency to the standard learning practices makes the learning process further efficient than the conventional way of learning. It is also efficient in promoting positive and progressive ethnic-racial identities and reduces potential achievement gaps. This literature review portion has crucially analysed the scholarly readings to understand the core concept of culturallyprogressive learning attitudes. 


\section{Methodology}

Research methodology develops a strong background based on which specific strategies and methods are selected for related data collection, efficient analysis and meeting the research objectives. Based on the research issues and theoretical underpinnings, the research methodology is selected that results in transparent results. Considering the research issue of the culture-based teaching-learning process, the study has considered detailed understanding and suitable data management processes to ensure positive results. In this aspect, the framework is developed with focus on relevant philosophies and approaches that formulated the best strategy to understand the educational relevance and purpose of culturally responsive pedagogy to teach English at rural school.

Research onion provides the chronological order of theoretical essence and strategies that are to be selected and used for conducting the research. As stated by Saunders et al. (2015), the peels of research onion help in the gradual shades agent of specific data collection and analysis techniques while considering the relevant research theories and approaches. However, it is critiqued based on its provided order of selection as data collection is the most prioritised aspect of research processes. Nonetheless, the strategic use of research onion stages can help in carefully designing the research method with specific relevance to research objectives.

\section{Research Philosophy}

Research philosophy provides the theoretical structure of conducting the research, including data gathering and its analysis. Positivism philosophy focuses on objective analysis while interpretivism emphasises on subjective understanding of research process. As stated by Edson, Henning \& Sankaran (2016), post-positivism helps in addressing research issues with scientific approaches without subjective perception. In this study, post-positivism research philosophy has been selected to understand the actual effects of culturally inclusive study processes in learning English language. The philosophy can provide direct understanding without perceptual differences and create scientific objectives with logical approaches and reasoning. Hence, post-positivism philosophy is suitable for determining the relation between culture responsive pedagogy and language learning.

\section{Research Design}

Research designs help in structuring and planning for the data collection, its analysis and related interpretation. The use of specific research design ensures relevant data collection. Among the different research designs, the experiment design helps in conducting experiences while the exploratory design helps in exploring new concepts (Leavy, 2017). Considering these, the research design employed in this study is action research. Kemmis and McTaggart (1988) cited in Burns (1990), action research occurs through a dynamic and complementary process which consists for four essential 'moments' of planning, action, observation and reflection.

\section{Research Strategy}

Research strategies are used for implementing the research process based on the theoretical considerations selected based on the research onion. Research strategies involve experiment, survey, case study, action research, ethnography, archival research and Grounded theory. Based on the research issues, the study has considered action research as it is the most suitable strategy for conducting research in the educational field. As commented by Bryman (2016), action research helps in implementing specific tasks to determine the relationship between the variables considered under the research program. In this study, action research can successfully establish the link between foreign language learning and culturally-responsive pedagogy.

\section{Data Collection}


For the data collection, it includes processes such as survey, interview and many more processes along with technical equipment to record data efficiently. In this research, the survey-interview method is selected based on the action research strategy. The survey-interview questionnaire consisted of questions for the sample population, which are to be recorded based on specific 5-6 scale Likert scale to quantify the data. It can aid in the efficient collection of data from targeted participants.

\section{Research Participants}

The participants of this research comprised of 20 pupils from Year 4 until Year 6, studying in primary school which is located at a remote area in Sarawak. Year 6 were included in this research as they do not sit for UPSR due to pandemic. These pupils are from the Iban community which come from three longhouses surrounding the school. The researcher found out that they have less interest in learning English and had limited vocabulary knowledge which then lead to poor writing skills. Apart from that, the large majority of their parents are not educated so English language is not essential for them to learn.

\section{Research Procedure}

This study employed Action Research (AR) with the model Kemmis \& McTaggart (1998). In implementing the action research, this study presented two cycles consisted of four stages including planning, acting, observing and reflecting described as followed:

\section{Cycle 1: Planning, acting, observing and reflecting}

In this stage, the concept of cycle was arranged. The researcher found out that the learners were having problem with their writing skills. Then, several items were prepared such as question papers, survey questions, lyrics from the internet and the audio of an Iban song. Acting was the implementation of planning stage. The respondent will listen to the audio of "Berkikis Bulu Betis" and personalize the lyrics to fit their own experiences, replacing some words in the song with new vocabulary provided on top of the questions. Observing was conducted when the acting stage was taking place. Reflecting was made based on the observation. It was done to analyse the effect of using an Iban songs in writing skills.

\section{Cycle 2: (Revised planning, acting, observation and reflecting)}

After the reflection done in cycle 1, the researcher came out with the improvised plan which is giving a topic without providing them with any words. The reason of improvising the exercise was because they felt restricted with the provided guidance. At the same time, it was inconvenient as they could not write the lyrics freely. The respondents carried out the implementation by writing the lyrics with their own ideas and the use of dictionary is allowed. Then, the researcher observed and facilitated the process of writing and make sure they can write the sentence in correct sentence structure. The reflection was done to identify the effectiveness of writing a lyric in English to an Iban song.

\section{Data Analysis}

In this study, the collected primary research data is to be analysed with the help of pre and post-test results, which are to be collected through survey. The analysis is supported by specific tables, graphs and charts, which are efficient in presenting the qualitative and quantitative data successfully. As commented by Bryman (2016), data analysis helps in achieving the required results by using tools. The data analysis in this study is supported by theoretical understanding and professional knowledge of data handling.

\section{Accessibility, Reliability and Validity}

The research has faced accessibility issues due to the extended period of lockdown and quarantine for COVID-19 pandemic. The research is reliable as it includes processes and strategies that have the 
potential to achieve the desired results in addition to the theoretical and evidence as support. Assessing the research based on its validation from other research processes, it can be said that the research is valid for achieving the results.

\section{Ethical Consideration}

The ethical consideration of this research included data protection principles and specific use of information for academic purposes only. Moreover, no directive statement and ethnically or culturally offensive statement is avoided to ensure respect. Consent from research participants is also considered for conducting the research.

\section{Findings, Discussion and Implication}

The survey result as conducted on 20 students from the primary section of the Iban community in Malaysia highlighted the efficacy of the culturally responsive pedagogical knowledge through the transformation of the local language based Iban song with English lyrics to enhance the vocabulary of the students as well as to enhance the writing skills of the students. As per the research results, eight students (40\%) and six students (30\%) agreed and strongly agreed on the fact that they like the Iban songs while three students ( nearly 15\%) opined that they didn't like the Iban songs. Interest and the preferences of the students play a vital role in the accumulation of knowledge. As stated by Bokiev et al. (2018), the subject that garner attention, interest plays a crucial role in facilitating the learning process among the students. Since, Iban songs were selected to enhance the English vocabulary and writing skills of the students, most of them who lacked interest in the song also didn't feel the interest to enrich their English vocabulary.

Figure 1: Graph showing the likelihood of Iban song among students

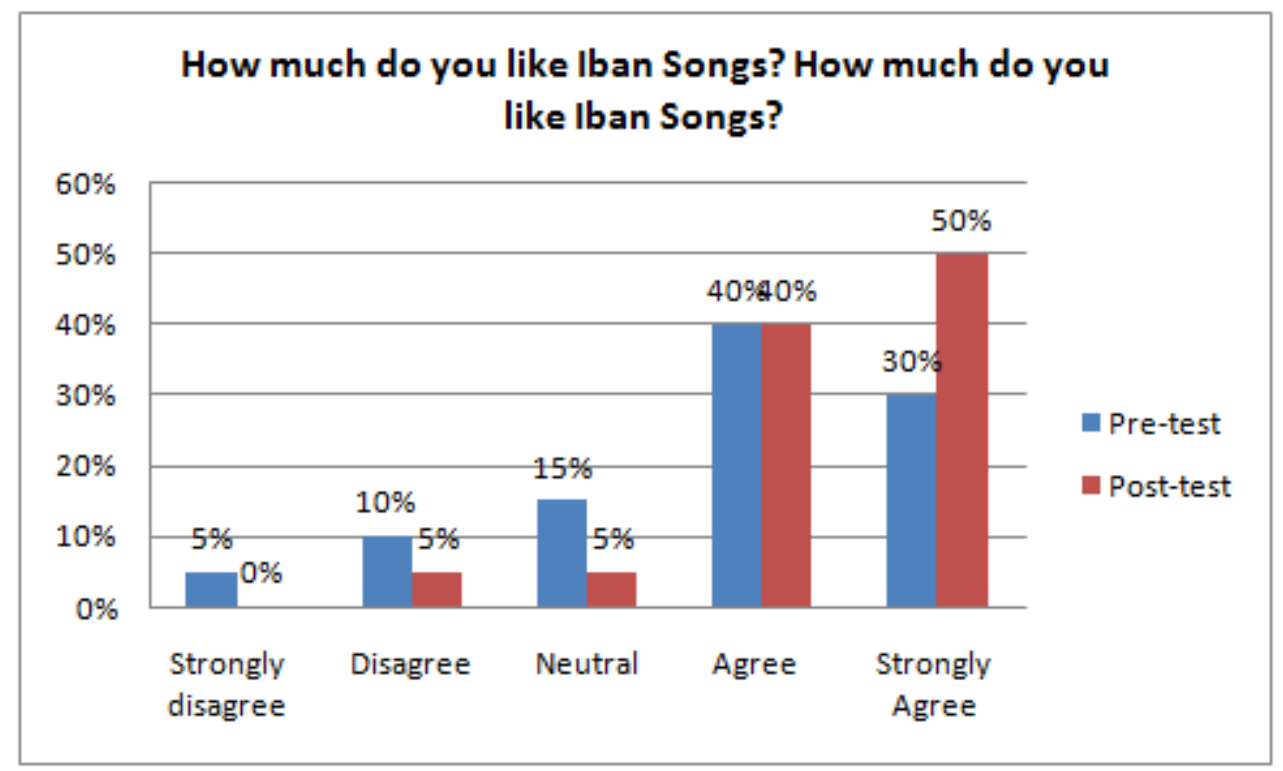

Pre-test survey results also highlighted the fact that nearly $10 \%$ of the students felt interested to learn and attend English class. In comparison, the majority of the students, nearly 55\%, didn't feel the interest to attend the English classes. The pre-test survey results were conducted where the students were asked to interchange the Iban song lyrics with the English vocabularies that were already provided to them. But, most of the students did not like the English language, and as a result, they too didn't feel the interest to transform the song lyrics with English vocabularies. The result obtained highlights the fact that since the students from the local Iban community were never exposed to foreign language and lack of communication in English within the family could be one of the probable reasons that affect the interest rate of the student in pursuing knowledge in English medium (Cruz et al. 2020). Lack of motivation could be another probable cause that resulted in an exhibition of the indifferent 
DOI: https://doi.org/10.47405/mjssh.v6i3.709

attitudes towards the English language. The students in the local community with limited access to technology, educational resources consider their limited boundary to be the only source of their existence and don't feel the need to explore the outside world. As stated by Kim, Song \& Coppersmith (2018), Globalisation has already resulted in the enormous changes within the living standards, the lifestyle of the people as a whole and the lack of understanding regarding the significance of the knowledge expansion through the enrichment of the English vocabularies creates a hindrance in the successful implementation of English learning.

Table 1: Pre-test survey results

\begin{tabular}{|c|c|c|c|c|c|c|}
\hline \multirow[t]{2}{*}{ No. } & \multirow[t]{2}{*}{ Statements } & \multicolumn{3}{|c|}{$\begin{array}{l}\text { Scale/ No. } \\
\text { Percentage }(\%)\end{array}$} & \multicolumn{2}{|c|}{ Respondents/ } \\
\hline & & 1 & 2 & 3 & 4 & 5 \\
\hline 1 & How much do you like Iban Songs? & 1 & 2 & 3 & 8 & 6 \\
\hline \multirow[t]{2}{*}{2} & How much do you like to attend English class? & $\begin{array}{l}5 \% \\
2\end{array}$ & $\begin{array}{l}10 \% \\
9\end{array}$ & $\begin{array}{l}15 \% \\
7\end{array}$ & $\begin{array}{l}40 \% \\
1\end{array}$ & $\begin{array}{l}30 \% \\
1\end{array}$ \\
\hline & & $10 \%$ & $45 \%$ & $35 \%$ & $5 \%$ & $5 \%$ \\
\hline \multirow[t]{2}{*}{3} & $\begin{array}{l}\text { Do you find it interesting to write lyrics in } \\
\text { English to a popular Iban song? }\end{array}$ & 7 & 2 & 5 & 4 & 2 \\
\hline & & $35 \%$ & $10 \%$ & $25 \%$ & $20 \%$ & $10 \%$ \\
\hline 4 & $\begin{array}{l}\text { Do you agree that you learn a lot with cultural } \\
\text { references of English language? }\end{array}$ & 1 & 3 & 2 & 8 & 6 \\
\hline & & $5 \%$ & $15 \%$ & $10 \%$ & $40 \%$ & $30 \%$ \\
\hline
\end{tabular}

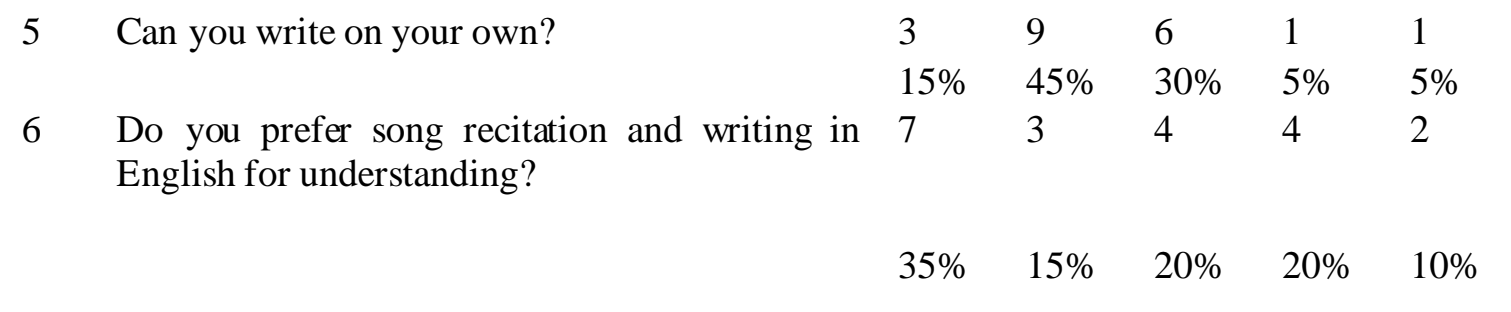

\begin{tabular}{lllll}
\hline Scale 1: Strongly disagree & Scale 2: Disagree & Scale 3: Neutral & Scale & $4:$ \\
Agree Scale 5: Strongly Agree & & & &
\end{tabular}

From the survey analysis, it can be concluded that majority of the students nearly $70 \%$ of the students strongly agreed on the fact that transformation of the Iban song lyrics with English vocabularies helps them to enrich their cultural knowledge, stories depicted through songs help them to discover and learn innovative things about their cultures, lifestyles, behaviour pattern of their predecessors and thus help 
them to be more culturally aware (Kurnia, 2017). But further analysis highlighted that nearly $45 \%$ of the students supported that they feel it difficult to write the song lyrics in the English language even after the provision of the vocabularies. As stated by Larson et al. (2018), The only factors that could be attributed to this cause are the lack of verbal interaction with the community members in English. They generally prefer local languages while they interact with their association. As per the idea of Warren (2018), Lack of expertise teachers, knowledge curriculum, complex and impractical learning approaches, discrimination based on the ethnicity and cultural background often demotivate the students to learn foreign languages effectively.

\section{Action process}

As opined by Mellom et al. (2018), culturally diverse pedagogical content can be viewed as an opportunity that broadens the scope of the knowledge enhancement of the students. The study findings based on the significance of the Iban songs in promoting the enhancement of literacy skills among the students highlighted that the enriched pedagogical content with cultural implication helps the students connect with the lyrics and vocabulary they are exposed to. As stated by Vidwans \& Faez (2019), they are planning action procedures to develop the English vocabulary content of the students from the particular community aimed at the conversion of the local Iban songs with English terminology from the already provided vocabulary content.

Figure 2: Graph showing preferences for English classes among students

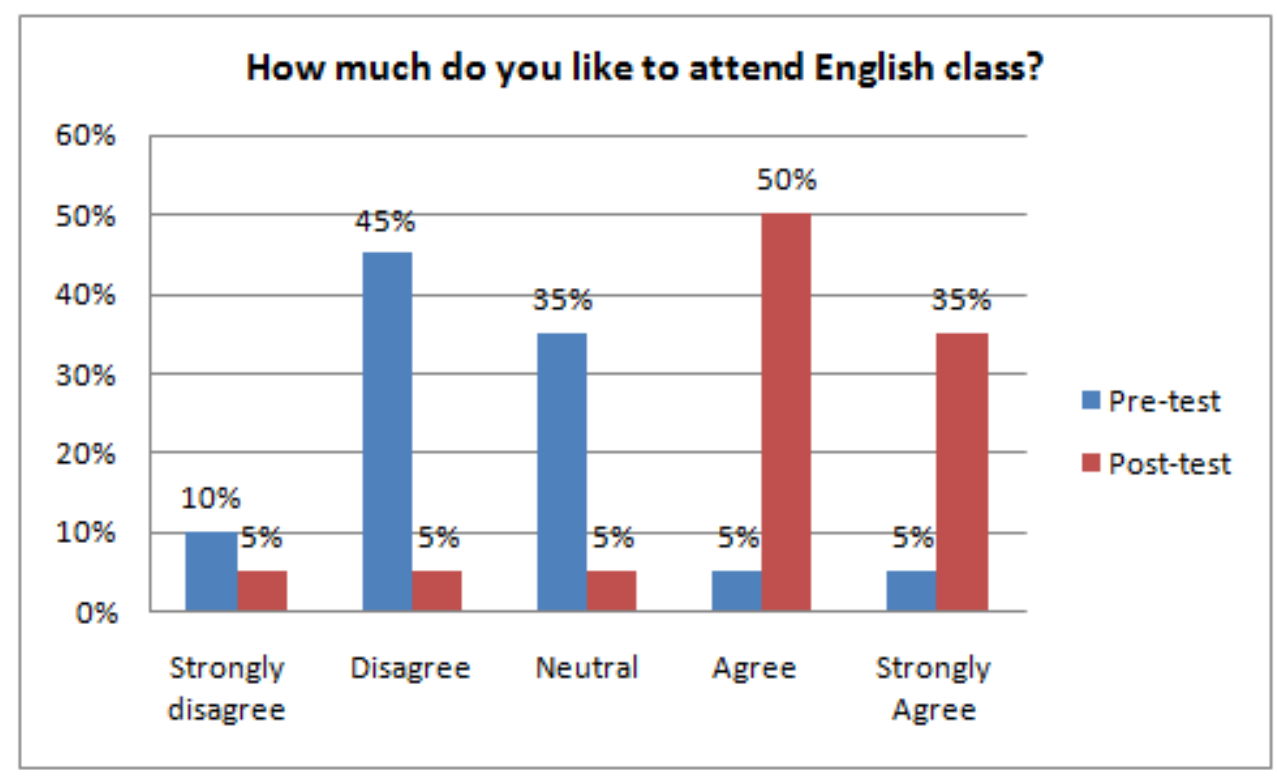

The action strategy was conducted to analyse the potentiality of the students about the transformation of the local lyrical words with the English terms as well as the students were provided with the opportunity to broaden their English knowledge by making them accustomed with their known culture (Murad et al. 2018). The result analysis of the planned Actions procedures highlighted that successful implementation of the action should occur only if students would feel the interest to attend English classes and transform the Iban song lyrics with accurate English words. The action strategy adopted highlights the innovative teaching approach that has been undertaken to generate awareness, motivation among the students and help them to identify the significance of the foreign languages in the global context.

\section{Implementing Action process}

Implementation of the Action procedures highlighted the successful conduction of the survey test by adopting a strategy in accordance with the fulfilment of the objectives that were decided at the planning phase. The students were asked to listen to one of the popular Iban songs and accordingly transform the 
DOI: https://doi.org/10.47405/mjssh.v6i3.709

lyrics with English vocabulary from the already added words mentioned in the questionnaire. As stated by Samuels et al. (2018), Successful implementation procedures result in the obtaining detailed information about the students' interest regarding the Iban songs, cultural awareness among the students and the factors that motivate the students to either prefer or ignore English language learning.

Figure 3: Graph showing cultural awareness through songs among students

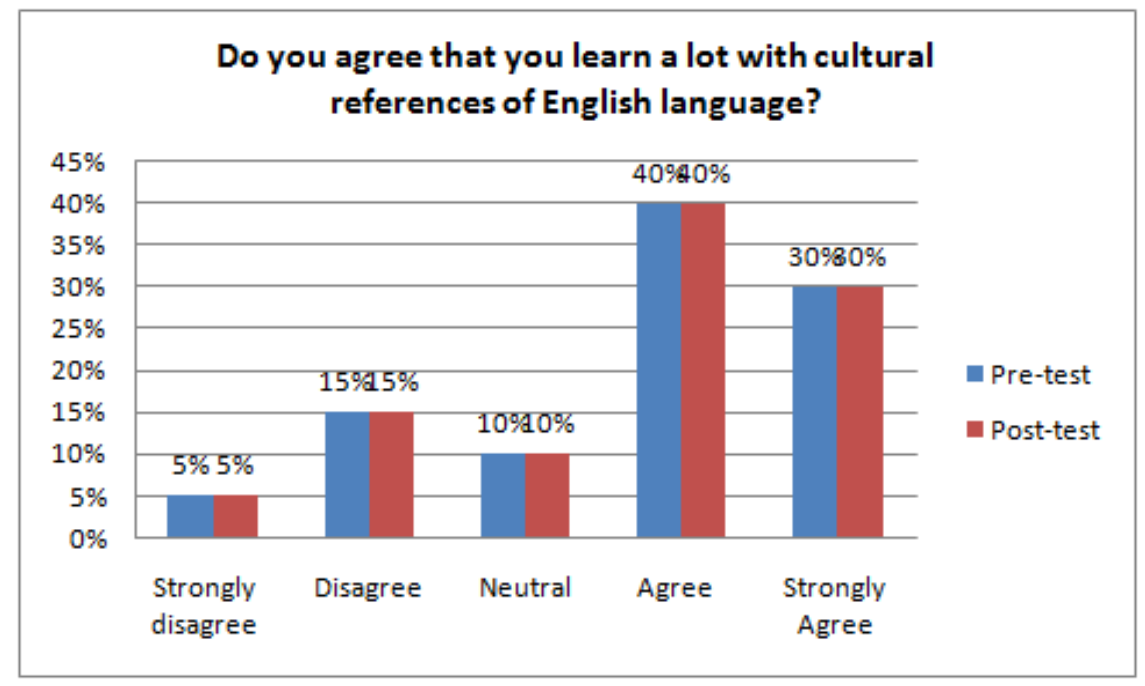

If the students successfully transform the Iban song lyrics with English terminology, it could be concluded that the students are more attached to the local languages, cultures. Thereby Samuels et al. (2017) stated that utilisation of the popular local songs that highlighted the ethnicity cultural richness of particular community could be an effective step to create awareness among the students about the English learning and popularizing English terminologies among them. Implementation of the actions procedures as decided in the planning phase served to be a sufficient basis to provide detailed knowledge that students feel much more familiar with the lock $\mathrm{lm}$ songs that depict cultural richness, however, restriction within the usage of vocabularies often delimits their potentiality to freely express their views and thereby affect their interest and motivation rates.

\section{Observation Process}

The procedures that were adopted fit obtaining the post-survey pilot test provided the students with the liberty to transform the Iban song's lyrics as per their understanding. Even they were allied to utilize various educational books and resources to transform the lyrics with English vocabularies.

Figure 4: Graph showing English writing skills among students

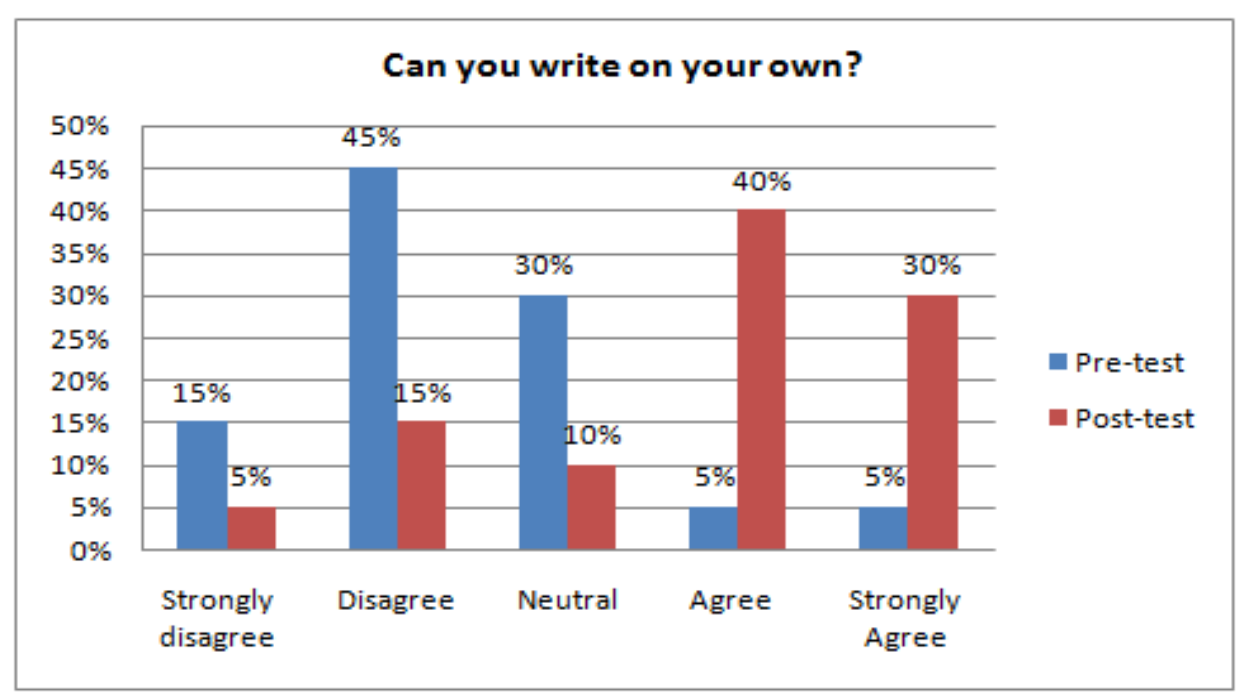


The survey analysis was further undertaken to observe the likelihood of the students towards the foreign language along with the difficulties that were encountered by them while writing in English. Nearly $90 \%$ of the students agreed with the fact that they like the Iban songs, and nearly $50 \%$ of the students agreed with the fact that they like to attend English classes. Initially, when students were given the opportunity to transform the local song lyrics with the english languages that are already provided to them, they felt a restriction in expressing their views and opinions while implementing the knowledge during writing. Lack of freedom to express their opinions and restricted directives created a monotony that affected their interest rate in learning a new language through their popular local music.

The pre-test survey result highlighted the fact that when students were asked to transform the local song with the English vocabulary from the already mentioned words only 10\%agreed the fact that they would be capable of writing in English comfortably. However, post-pilot surveys highlight the fact that when these students were given the liberty to express the lyrical words using English vocabulary as per their understanding, nearly $70 \%$ of them strongly opined the fact that they are capable of comfortably writing the songs using English vocabulary.

Table 2: Post-test survey results

\begin{tabular}{|c|c|c|c|c|c|c|}
\hline \multirow{2}{*}{\multicolumn{2}{|c|}{ No. Statements }} & \multicolumn{3}{|c|}{$\begin{array}{ll}\text { Scale/ No. of } \\
\text { Percentage }(\%)\end{array}$} & \multicolumn{2}{|c|}{ Respondents/ } \\
\hline & & 1 & 2 & 3 & 4 & 5 \\
\hline 1 & How much do you like Iban Songs? & 0 & 1 & 1 & 8 & 10 \\
\hline 2 & How much do you like to attend English class? & $\begin{array}{l}0 \% \\
1\end{array}$ & $\begin{array}{l}5 \% \\
1\end{array}$ & $\begin{array}{l}5 \% \\
1\end{array}$ & $\begin{array}{l}40 \% \\
10\end{array}$ & $\begin{array}{l}50 \% \\
7\end{array}$ \\
\hline
\end{tabular}

$5 \% \quad 5 \% \quad 5 \% \quad 50 \% \quad 35 \%$

3 Do you find it interesting to write lyrics in $1 \quad 1 \quad \begin{array}{lllll}0 & 1 & 10 & 8\end{array}$ English to a popular Iban song?

$5 \% \quad 5 \% \quad 0 \% \quad 50 \% \quad 40 \%$

$\begin{array}{llllllll}4 & \text { Do you agree that you learn a lot with cultural } & 1 & 3 & 2 & 8 & 6\end{array}$ references of English language?

$5 \% \quad 15 \% \quad 10 \% \quad 40 \% \quad 30 \%$

$\begin{array}{lllllll}5 & \text { Can you write on your own? } & 1 & 3 & 2 & 8 & 6 \\ & & 5 \% & 15 \% & 10 \% & 40 \% & 30 \% \\ 6 & \text { Do you prefer song recitation and writing in } & 0 & 3 & 3 & 6 & 8\end{array}$ 
DOI: https://doi.org/10.47405/mjssh.v6i3.709

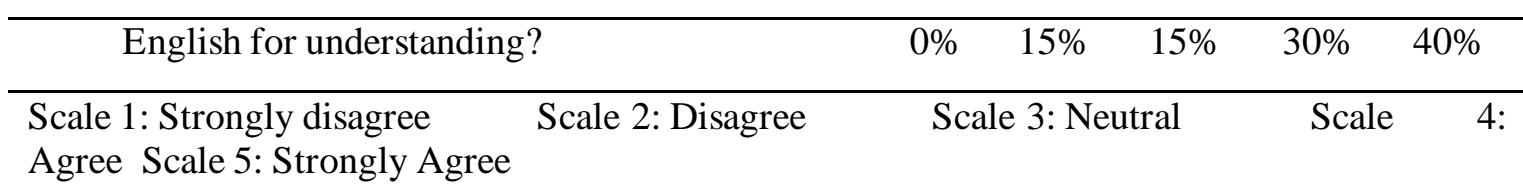

Post pilot survey results highlighted the fact that $70 \%$ of them strongly supported that they feel the strategy of listening to Iban songs and transforming the lyrics with English vocabulary not only enhance their literacy skills but also make them culturally aware and help them to gain insights about the diverse cultural knowledge that existed within their community. Lack of practices, exposure, adequate resources, expert educators and appropriate teaching strategy are some of the barriers that affected their knowledge acquisition skills. However, the modification within the teaching strategy by providing them with the liberty to express their vows and accordingly transform the local song lyrics with English words has seemed to generate interest among the students to recite and write songs in English language to enhance their English terminology. Nearly $70 \%$ of the students felt comfortable reciting and writing songs in English.

\section{Reflecting and Evaluating Process}

The evaluation phase of the test result highlights the critical analysis of the objectives focused upon to fulfil the survey criteria. Protest pilot surveys restricted the students' scope of vocabulary usage and were asked to transform the local Iban song lyrics with previously mentioned words as per their understanding. Simultaneously, the post-survey results provided the liberty to utilize appropriate resources to familiarize the students with English vocabulary by utilizing the Iban song. As opined by Shandruk et al. (2017), the evaluation process highlighted the strategy that would be effective in enhancing the learning acquisition skills of the students. Reflective procedures based on the survey analysis highlighted the fact that students were more comfortable in using English vocabulary when the theory was given the liberty to express their opinions and views as per their understanding.

Figure 5: Graph showing the preferences of students in English song recitation and writing

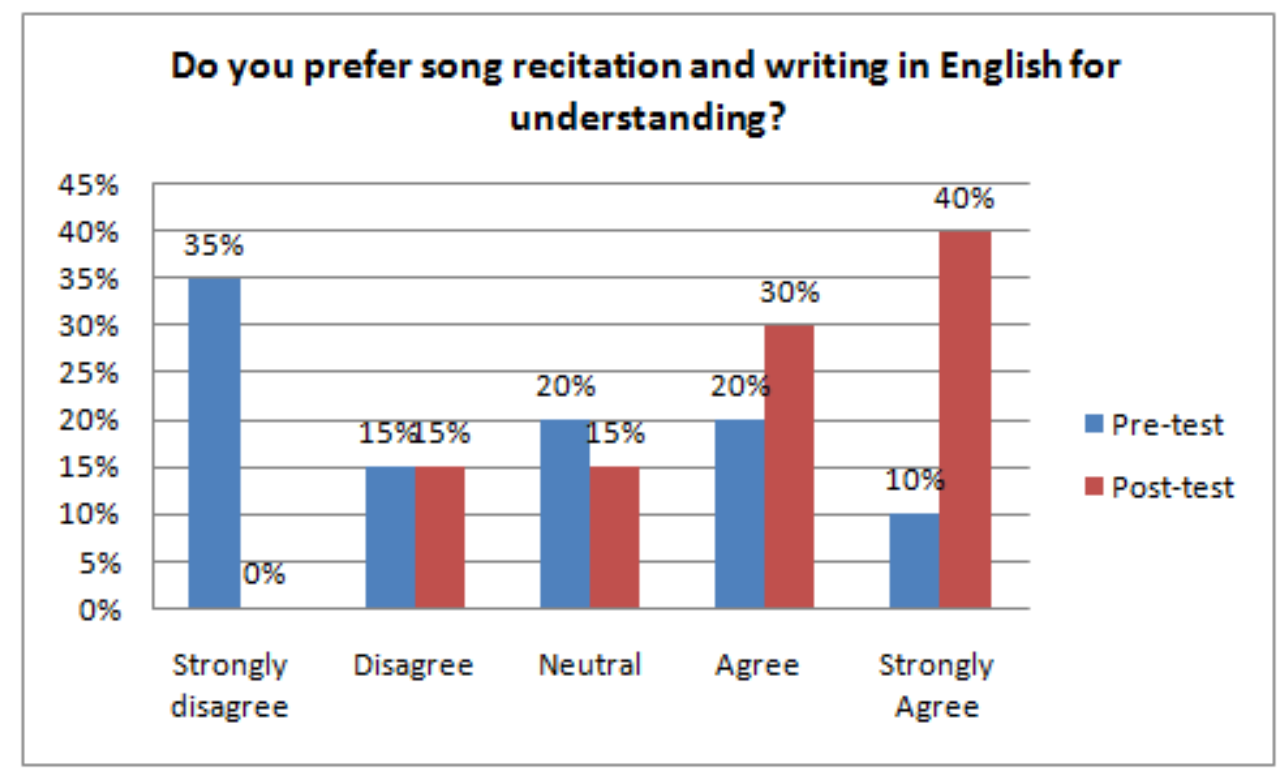

Conduction of the evaluation process was undertaken to decipher the crucial factors that prevented the students from learning foreign languages and the difficulties that they encountered while writing English. According to Siwatu et al. (2017), Lack of exposure, as well as lack of frequent usage of English vocabulary among their community along with the inconvenient teaching practices, is considered to be the major factors that prevented the students from accepting and applying English language during their normal conversation. 


\section{Conclusion}

This study has examined how a teacher should have skills in tackle the students' interest and motivation by getting close to their culture. It is not an easy task to motivate the students in learning the language that is not familiar to them. Teachers should not expect them to love the language instantly, it does take continuous time. Knowing their culture and implementing fun learning such as writing lyrics in English related to their background therefore should be the main concern of teachers as it is the key factor for them to learn the language. In school, teaching English is not merely about completing the syllabus in the textbook instead it should be carefully planned to incorporate meaningful learning process and maximize the exposure of English language. In addition, the use of indigenous Iban song to motivate rural pupils in writing in English is a good way to be implemented in the classroom in improving their English. More comprehensive research related to this pedagogy should be carried out in the future as it contributes positive impact in the context of education field especially for schools in rural area.

\section{References}

Azungah, T. (2018). Qualitative research: deductive and inductive approaches to data analysis. Qualitative Research Journal. Retrieved from https://doi.org/10.1108/QRJ-D-1800035

Bassey, M. O. (2016). Culturally responsive teaching: Implications for educational justice. Education Sciences, 6(4), 35. doi.org/10.3390/educsci6040035

Bernard, H. R. (2017). Research methods in anthropology: Qualitative and quantitative approaches. London, United Kingdom: Rowman \& Littlefield.

Bokiev, D., Bokiev, U., Aralas, D., Ismail, L., \& Othman, M. (2018). Utilizing music and songs to promote student engagement in ESL classrooms. International Journal of Academic Research in Business and Social Sciences, 8(12), 314-332. Retrieved from: https://pdfs. semanticscholar.org/f53c/849b3f0459f749e61b1197f125fad9a457b2.pdf

Bokiev, D., Bokiev, U., Aralas, D., Ismail, L., \& Othman, M. (2018). Utilizing music and songs to promote student engagement in ESL classrooms. International Journal of Academic Research in Business and Social Sciences, 8(12), 314-332. Retrieved from: https://pdfs.semanticscholar.org/f53c/849b3f0459f749e61b1197f125fad9a457b2.pdf

Bryman, A. (2016). Social research methods. Oxford, United Kingdom: Oxford university press.

Callaway, R. F. (2016). A correlational study of teacher efficacy and culturally responsive teaching techniques in a southeastern urban school district. Retrieved from: https://digitalcommons.gardner-

webb.edu/cgi/viewcontent.cgi?article $=1152 \&$ context=education_etd

Carter Andrews, D. J., Richmond, G., Warren, C. A., Petchauer, E., \& Floden, R. (2018). A call to action for teacher preparation programs: Supporting critical conversations and democratic action in safe learning environments. DOI: 10.1177/0022487118766510

Cruz, R. A., Manchanda, S., Firestone, A. R., \& Rodl, J. E. (2019). An Examination of Teachers' Culturally Responsive Teaching Self-Efficacy. Teacher Education and Special Education,

Cruz, R. A., Manchanda, S., Firestone, A. R., \& Rodl, J. E. (2020). An examination of teachers' culturally responsive teaching self-efficacy. Teacher Education and Special Education, 43(3), 197-214. Retrieved from: https://www.researchgate.net/profile/Sarah_Manchanda2/project/Teachers-Self-Efficacy-inCulturally-Responsive-

Teaching/attachment/5d811420cfe4a7968dcc52df/AS:804169610969088@1568740384091/do wnload/Cruz+Manchanda+Firestone+Rodl+2019.pdf?context=ProjectUpdatesLog

Cruz, R. A., Manchanda, S., Firestone, A. R., \& Rodl, J. E. (2020). An examination of teachers' culturally responsive teaching self-efficacy. Teacher Education and Special Education, 43(3), 197-214.

Retrieved from: https://www.researchgate.net/profile/Sarah_Manchanda2/project/Teachers-Self-Efficacy-inCulturally-Responsive- 
Teaching/attachment/5d811420cfe4a7968dcc52df/AS:804169610969088@ 1568740384091/do wnload/Cruz+Manchanda+Firestone+Rodl+2019.pdf?context=ProjectUpdatesLog

De Jager, T. (2019). Millennial science student teachers' views on decolonisation and culturally responsive teaching. Journal of Education (University of KwaZulu-Natal), (76), 185-201. (Online) Retrieved from: http://www.scielo.org.za/scielo.php?pid=S252098682019000200010\&script=sci_arttext\&tlng=es [Accessed on 15 June 2020]

Edson, M. C., Henning, P. B., \& Sankaran, S. (Eds.). (2016). A guide to systems research: Philosophy, processes and practice (Vol. 10). Berlin, Germany: Springer.

Fasasi, R. A. (2017). Effects of ethnoscience instruction, school location, and parental educational status on learners' attitude towards science. International Journal of Science Education, 39(5), 548-564.

Gay, G. (2015). The what, why, and how of culturally responsive teaching: International mandates, challenges, and opportunities. Multicultural education review, 7(3), 123-139. Retrieved from https://doi.org/10.1080/2005615X.2015.1072079

Genao, S. (2016). Culturally responsive pedagogy: Reflections on mentoring by educational leadership candidates. Issues in Educational Research,26(3), 431. (Online) Retrieved from: https://www.iier.org.au/iier26/genao.html [Accessed on 16 June 2020]

George, M. L. (2018). Narrowing the Cultural Divide: Preparing Culturally Responsive Educators by Instituting Transformative Pedagogical Pre-service Training Programs (Doctoral dissertation, $\begin{array}{lll}\text { Northeastern University). } & \text { Retrieved }\end{array}$ https://repository.library.northeastern.edu/files/neu:m044c687k/fulltext.pdf

Gist, C., Jackson, I., Nightengale-Lee, B., \& Allen, K. (2019). Culturally Responsive Pedagogy in Teacher Education. In Oxford Research Encyclopedia of Education. DOI: 10.1093/acrefore/9780190264093.013.266

Han, J. B. (2017). Developing a Scale for Culturally Responsive Practice: Validation, Relationship with School Organizational Factors, and Application. Michigan: Michigan State University.

Han, J. B. (2017). Developing a Scale for Culturally Responsive Practice: Validation, Relationship with School Organizational Factors, and Application. Michigan State University.

Heitner, K. L., \& Jennings, M. (2016). Culturally responsive teaching knowledge and practices of online faculty. Online Learning, 2O(4), 54-78. Retrieved from: https://files.eric.ed.gov/fulltext/EJ1124634.pdf

Khalifa, M. A., Gooden, M. A., \& Davis, J. E. (2016). Culturally responsive school leadership: A synthesis of the literature. Review of Educational Research, 86(4), 1272-1311. DOI: $10.3102 / 0034654316630383$

Kim, S., Song, K., \& Coppersmith, S. (2018). Creating an interactive virtual community of linguistically and culturally responsive content teacher-learners to serve English learners. Contemporary Issues in Technology and Teacher Education, 18(2), 442-466. Retrieved from: https://www.learntechlib.org/primary/p/178237/paper_178237.pdf

Kim, S., Song, K., \& Coppersmith, S. (2018). Creating an interactive virtual community of linguistically and culturally responsive content teacher-learners to serve English learners. Contemporary Issues in Technology and Teacher Education, 18(2), 442-466. Retrieved from: https://www.learntechlib.org/primary/p/178237/paper_178237.pdf

Kurnia, C. (2017). Increasing Young Learners' Vocabulary Mastery By Using English Songs. JELE (Journal of English Language and Education),3(1), 42-53. Retrieved from: http://ejurnal.mercubuana-yogya.ac.id/index.php/jele/article/viewFile/266/250

Kurnia, C. (2017). Increasing Young Learners' Vocabulary Mastery By Using English Songs. JELE (Journal of English Language and Education), 3(1), 42-53. Retrieved from: http://ejurnal.mercubuana-yogya.ac.id/index.php/jele/article/viewFile/266/250

Larson, K. E., Pas, E. T., Bradshaw, C. P., Rosenberg, M. S., \& Day-Vines, N. L (2018). Examining how proactive management and culturally responsive teaching relate to student behavior: Implications for measurement and practice. School Psychology Review, 47(2), 153-166. Retrieved from: https://files.eric.ed.gov/fulltext/EJ1182041.pdf

Larson, K. E., Pas, E. T., Bradshaw, C. P., Rosenberg, M. S., \& Day-Vines, N. L (2018). Examining how proactive management and culturally responsive teaching relate to student behavior: Implications for measurement and practice. School Psychology Review,47(2), 153-166. Retrieved from: https://files.eric.ed.gov/fulltext/EJ1182041.pdf 
Larson, K. E., Pas, E. T., Bradshaw, C. P., Rosenberg, M. S., \& Day-Vines, N. L (2018). Examining how proactive management and culturally responsive teaching relate to student behavior: Implications for measurement and practice. School Psychology Review, 47(2), 153-166. Retrieved from: https://files.eric.ed.gov/fulltext/EJ1182041.pdf

Leavy, P. (2017). Research design: Quantitative, qualitative, mixed methods, arts-based, and community-based participatory research approaches. New York, United States: Guilford Publications.

Leonard, J., Mitchell, M., Barnes-Johnson, J., Unertl, A., Outka-Hill, J., Robinson, R., \& Hester-Croff, C. (2018). Preparing teachers to engage rural students in computational thinking through robotics, game design, and culturally responsive teaching. Journal of Teacher Education, 69(4), 386-407. DOI: $10.1177 / 0022487117732317$

Lucey, T. A., \& White, E. S. (2017). Mentorship in Higher Education: Compassionate Approaches Supporting Culturally Responsive Pedagogy. Multicultural Education, 24(2), 11-17. Retrieved from: https://files.eric.ed.gov/fulltext/EJ1150567.pdf

McKinney, S., Tomovic, C., Grant, M., \& Hinton, K. (2017). Increasing STEM Competence in Urban, High Poverty Elementary School Populations. K-12 STEM Education, 3(4), 267-282. Retrieved from: https://www.learntechlib.org/p/209583/

Mellom, P. J., Straubhaar, R., Balderas, C., Ariail, M., \& Portes, P. R. (2018). "They come with nothing:" How professional development in a culturally responsive pedagogy shapes teacher attitudes towards Latino/a English language learners. Teaching and Teacher Education, 71, 98107.

Retrieved

from: https://www.academia.edu/download/57206500/Mellom_Straubhaar_et_al_2018.pdf

Mellom, P. J., Straubhaar, R., Balderas, C., Ariail, M., \& Portes, P. R. (2018). "They come with nothing:" How professional development in a culturally responsive pedagogy shapes teacher attitudes towards Latino/a English language learners. Teaching and Teacher Education, 71, 98$107 . \quad$ Retrieved from: https://www.academia.edu/download/57206500/Mellom_Straubhaar_et_al_2018.pdf

Mette, I. M., Nieuwenhuizen, L., \& Hvidston, D. J. (2016). Teachers' Perceptions of Culturally Responsive Pedagogy and the Impact on Leadership Preparation: Lessons for Future Reform Efforts. International Journal of Educational Leadership Preparation, 11(1), n1.

Morrison, A., Morrison, A., Rigney, L. I., Hattam, R., \& Diplock, A. (2019). Toward an Australian culturally responsive pedagogy: A narrative review of the literature. Adelaide, Australia: University of South Australia.

MUBAROK, I. S. C. (2019). THE USE OF ENGLISH SONG LYRIC TO IMPROVE STUDENTS WRITING SKILLS IN THE TENTH GRADE STUDENTS OF SMK TELEKOMUNIKASI TUNAS HARAPAN(Doctoral dissertation, IAIN SALATIGA). Retrieved from: http://erepository.perpus.iainsalatiga. ac.id/6026/1/Imam\%20Sufi\%20Chusni\%20M\%20\%28230 30-15-0079\%29-dikompresi.pdf

Murad, D., Wang, R., Turnbull, D., \& Wang, Y. (2018, October). SLIONS: A karaoke application to enhance foreign language learning. In Proceedings of the 26th ACM international conference on Multimedia (pp. 1679-1687). Retrieved from: https://smcnus.comp.nus.edu.sg/wpcontent/uploads/2018/08/ACMMM18_PaperID1029_CameraReadyVersion.pdf

Murad, D., Wang, R., Turnbull, D., \& Wang, Y. (2018, October). SLIONS: A karaoke application to enhance foreign language learning. In Proceedings of the 26th ACM international conference on Multimedia (pp. 1679-1687). Retrieved from: https://smcnus.comp.nus.edu.sg/wpcontent/uploads/2018/08/ACMMM18_PaperID1029_CameraReadyVersion.pdf

Patrick, R. (2019). Comprehensible Input and Krashen's theory. Journal of Classics Teaching, 20(39), $37-44$.

Pirbhai-Illich, F., Pete, S., \& Martin, F. (Eds.). (2017). Culturally responsive pedagogy: Working towards decolonisation, indigeneity and interculturalism. Berlin, Germany: Springer.

Rogach, O. V., Frolova, E. V., \& Ryabova, T. M. (2018). Theory of" Trust" in the Focus of Expectation Study Concerning Educational Space Key Actors. European Journal of Contemporary Education, 7(2), 392-399. Retrieved from: https://files.eric.ed.gov/fulltext/EJ1181889.pdf

Salman, N. (2019). Culturally Responsive Pedagogy for In-service BC Teachers. Retrieved from: http://dspace.library.uvic.ca/handle/1828/10875 
Samuels, A. J. (2018). Exploring Culturally Responsive Pedagogy: Teachers' Perspectives on Fostering Equitable and Inclusive Classrooms. SRATE Journal, 27(1), 22-30. Retrieved from: https://files.eric.ed.gov/fulltext/EJ1166706.pdf

Samuels, A. J. (2018). Exploring Culturally Responsive Pedagogy: Teachers' Perspectives on Fostering Equitable and Inclusive Classrooms. SRATE Journal, 27(1), 22-30. Retrieved from https://files.eric.ed.gov/fulltext/EJ1166706.pdf

Samuels, A. J. (2018). Exploring Culturally Responsive Pedagogy: Teachers' Perspectives on Fostering Equitable and Inclusive Classrooms. SRATE Journal, 27(1), 22-30. Retrieved from: https://files.eric.ed.gov/fulltext/EJ1166706.pdf

Samuels, A. J., Samuels, G. L., \& Cook, T. M. (2017). Examining perceptions of culturally responsive pedagogy in teacher preparation and teacher leadership candidates. SRATE Journal, 26(2), 5060. Retrieved from: https://files.eric.ed.gov/fulltext/EJ1152453.pdf

Samuels, A. J., Samuels, G. L., \& Cook, T. M. (2017). Examining perceptions of culturally responsive pedagogy in teacher preparation and teacher leadership candidates. SRATE Journal, 26(2), 5060. Retrieved from: https://files.eric.ed.gov/fulltext/EJ1152453.pdf

Samuels, A. J., Samuels, G. L., \& Cook, T. M. (2017). Examining perceptions of culturally responsive pedagogy in teacher preparation and teacher leadership candidates. SRATE Journal, 26(2), 5060. Retrieved from https://files.eric.ed.gov/fulltext/EJ1152453.pdf

Samuels, A. J., Samuels, G. L., \& Cook, T. M. (2017). Examining perceptions of culturally responsive pedagogy in teacher preparation and teacher leadership candidates. SRATE Journal, 26(2), 5060. Retrieved from: https://files. eric.ed.gov/fulltext/EJ1152453.pdf

Saunders, M. N., Lewis, P., Thornhill, A., \& Bristow, A. (2015). Understanding research philosophy and approaches to theory development. Retrieved from http://oro.open.ac.uk/id/eprint/53393

Savin-Baden, M., \& Tombs, G. (2017). Research methods for education in the digital age. London, United Kingdom: Bloomsbury Publishing.

Shandruk, S., 2017. Songs in the English language classroom. Наукові записки [Кіровоградського державного педагогічного університету імені Володимира Винниченка]. Сер.: Педагогічні науки, (152), pp.60-63. Retrieved from: http://www.irbis-nbuv.gov.ua/cgibin/irbis_nbuv/cgiirbis_64.exe?C21COM=2\&I21DBN=UJRN\&P21DBN=UJRN\&IMAGE_FIL E_DOWNLOAD=1\&Image_file_name=PDF/Nz_p_2017_152_15.pdf

Shandruk, S., 2017. Songs in the English language classroom. Наукові записки [Кіровоградського державного педагогічного університету імені Володимира Винниченка]. Сер.: Педагогічні науки, (152), pp.60-63. Retrieved from: http://www.irbis-nbuv.gov.ua/cgibin/irbis_nbuv/cgiirbis_64.exe?C21COM=2\&I21DBN=UJRN\&P21DBN=UJRN\&IMAGE_FIL E_DOWNLOAD=1\&Image_file_name=PDF/Nz_p_2017_152_15.pdf

Shayakhmetova, L., Shayakhmetova, L, Ashrapova, A., \&Zhuravleva, Y. (2017). Using songs in developing intercultural competence. Journal of History Culture and Art Research, 6(4), 639646

Siwatu, K. O., Putman, S. M., Starker-Glass, T. V., \& Lewis, C. W. (2017). The culturally responsive classroom management self-efficacy scale: Development and initial validation. Urban Education, 52(7), 862-888. Retrieved from: http://citeseerx.ist.psu.edu/viewdoc/download?doi=10.1.1.978.3688\&rep=rep1\&type=pdf

Siwatu, K. O., Putman, S. M., Starker-Glass, T. V., \& Lewis, C. W. (2017). The culturally responsive classroom management self-efficacy scale: Development and initial validation. Urban $\begin{array}{llll}\text { Education, 52(7), } & \text { 862-888. } & \text { Retrieved }\end{array}$ http://citeseerx.ist.psu.edu/viewdoc/download?doi=10.1.1.978.3688\&rep=rep1\&type=pdf

Taherdoost, H. (2016). Sampling methods in research methodology; how to choose a sampling technique for research. How to Choose a Sampling Technique for Research (April 10, 2016). Retrieved from https://hal.archives-ouvertes.fr/hal-02546796/document

Tamrin, M., Muis, M., \& Nursyamsi, I. (2018). TRAINING MANAGEMENT OF APPRENTICESHIP PROGRAM: A COMPARISON OF EXPECTATION THEORY, SELF DETERMINATION THEORY, AND SOCIAL IDENTITY THEORY. Retrieved from: http://www.scirj.org/papers-1218/scirj-P1218597.pdf

Tanner, M. R. (2019). What is the Impact of a New Initiative Designed to Stimulate Culturally Responsive Practices in a High Performing Suburban School? (Doctoral dissertation, Miami 
University)

Retrieved

from: https://etd.ohiolink.edu/!etd.send_file?accession=miami1563831319342741\&disposition=inline

Thomas, G. (2017). How to do your research project: A guide for students. California, United States: Sage.

Vidwans, M., \& Faez, F. (2019). Teaching in Linguistically and Culturally Diverse Classrooms in Canada: Self-Efficacy Perceptions of Internationally Educated Teachers. TESL Canada 48-67. Retrieved from: https://teslcanadajournal.ca/tesl/index.php/tesl/article/download/1357/1183

Vidwans, M., \& Faez, F. (2019). Teaching in Linguistically and Culturally Diverse Classrooms in Canada: Self-Efficacy Perceptions of Internationally Educated Teachers. TESL Canada Journal, 36(2), 48-67. Retrieved

from: https://teslcanadajournal.ca/tesl/index.php/tesl/article/download/1357/1183

Wah, Y. L. \& Nasri, N. B. M. (2019). A Systematic Review: The Effect of Culturally Responsive Pedagogy on Student Learning and Achievement. INTERNATIONAL JOURNAL OF ACADEMIC RESEARCH IN BUSINESS AND SOCIAL SCIENCES, 9(5). Retrieved from: http://hrmars.com/hrmars_papers/A_Systematic_Review_The_Effect_of_Culturally_Responsiv e_Pedagogy_on_Student_Learning_and_Achievement.pdf

Warren, C. A. (2018). Empathy, teacher dispositions, and preparation for culturally responsive pedagogy. Journal of Teacher Education, 69(2), 169-183. Retrieved from: https://www.academia.edu/download/54500021/Empathy_Teacher_Dispositions_and_CRP.p $\underline{\mathrm{df}}$

Warren, C. A. (2018). Empathy, teacher dispositions, and preparation for culturally responsive pedagogy. Journal of Teacher Education, 69(2), 169-183. DOI: 10.1177/0022487117712487

Warren, C. A. (2018). Empathy, teacher dispositions, and preparation for culturally responsive pedagogy. Journal of Teacher Education, 69(2), 169-183. Retrieved from: https://www.academia.edu/download/54500021/Empathy_Teacher_Dispositions_and_CRP.p df

Wildavsky, A. (2018). Culture and social theory. Abingdon: Routledge. 